\title{
Software testing blamed for Ariane failure
}

Paris. Inadequate computer-software testing has been officially identified as the cause of the explosion of the European Ariane-5 satellite launcher 37 seconds into its maiden flight on 4 June.

Jean-Marie Luton, director general of the European Space Agency (ESA), said at a press conference in Paris last week, held to present the findings an independent board of inquiry, that the mishap was due to ESA's failure to upgrade adequately the flight control and guidance systems used on board Ariane-4.

The mishap will delay the Ariane-5 programme by six months and increase its cost by two to four per cent - or FFr900 million (US $\$ 180$ million) to FFr1.5 billion. "We are all to blame," said Luton.

The loss in the explosion of the four scientific satellites that were to be launched by Ariane- 5 has added ECU400 million (US\$307 million) to the cost of the accident, according to ESA's science director, Roger
Bonnet. The satellites were part of the Cluster mission to study over two years the relation between the Sun and the Earth's magnetic field.

Their destruction "represents the loss of much unpaid work by scientists", Bonnet said. A total of 200 scientists from Germany, France and Britain, the main movers behind Cluster, as well as researchers from the United States, Japan and Russia, worked on the programme. Bonnet said the prototype of Ariane-5: failure occurred 37 seconds after lift-off. the Cluster satellites will be refitted, "possibly to be launched by Ariane5 on its next flight next spring". The new scientific mission has, aptly, been named Phoenix (see Nature 382, 102; 1996).

Bonnet stressed that Phoenix's findings would not be comparable to those planned

\section{Budget cuts hit German funding for ESA}

Munich. Germany's financial contribution to the European Space Agency (ESA) seems destined to fall significantly next year, in line with the reductions being planned in its support to five international research laboratories (see Nature 382, 285; 1996).

As part of its federal budget announced last month, the German research ministry proposed a cut of DM100 million (US $\$ 68$ million) in the budget of the German space agency, DARA. It is also proposing further savings by merging DARA with the national air and space research centre, Deutsche Forschungsanstalt für Luft- und Raumfahrt (DLR).

The space agency has a total budget of DM1.35 billion, DM1 billion of which is designated for ESA. If the cut is approved by parliament this autumn as seems likely - Germany's contribution to ESA will be reduced by at least 7.4 per cent. This figure could be even higher if Germany decides to protect its national space programmes. Christian Lenzer, science spokesman for the ruling Christian Democrat party, says that his party supports such a move.

Decisions have yet to be made on the precise division of the cuts between national and international space programmes. But Gernot Hartmann, DARA's director of science programmes, says that he believes the current ratio of spending is likely to be maintained. He says commitments to ESA are expected to be honoured. "The cuts will probably mean that we will not be able to start any new ESA projects," he says.

Jürgen Rüttgers, the German research minister, has given the directors of DARA and DLR until October to make suggestions on how their proposed merger could be made most effective.

DARA was set up in 1989 to coordinate the space activities of several ministries. But in practice it has concentrated almost exclusively on the interests of the research ministry. Other ministries with interests in space, such as telecommunications, transport and defence, have not been prepared to hand over responsibility. So the agency's staff of 270 has ended up handling a relatively small budget.

Jan-Baldem Mennicken, director general of DARA, says that any merger proposal that DARA and DLR agree will avoid a conflict of interest between management of space programmes and the research and development activities of DLR, which some scientists fear. Hartmann also says relations with ESA should remain unchanged.

The opposition Social Democrats have criticized the merger, saying that it will adversely affect the continuity of space science policy. Instead, the party argues, other ministries should be forced to transfer their space programmes to DARA, as had been agreed earlier this summer by parliament. But given the pressures on the German budget, many scientists are not surprised by the sudden squeeze on space science.

Alison Abbott \& Quirin Schiermeier for Cluster. "Cluster was to fly in a pyramid configuration, whereas Phoenix will be onedimensional." He added: "A study is under way for a new three-dimensional measurement mission but its objectives have not been defined. It will probably take place around 2000 but it is likely to be scaled down compared to the original programme."

Bonnet maintained that the loss of the satellites would not jeopardize ESA's relations with its partners in the international space research community. The US National Aeronautics and Space Administration (NASA), a major partner in the Cluster project, is in particular to remain involved in Phoenix and possibly in future projects, he said.

"Solidarity in this type of situation is de rigueur," he said. "We did not alter our relationship with NASA when the Hubble telescope ran into trouble."

But Bonnet is worried about the future of ESA's research programmes. "Ministers [of the countries which operate ESA] last year ordered a ten per cent reduction in science funding by 1998, and I don't see an end to this trend in the absence of political will for progress in space research," he says.

Whatever cuts may be in store for European space scientists (see box, left), there is little doubt that Ariane- 5 will be maintained, as it is an essentially commercial project. The inquiry board, headed by Professor Jacques-Louis Lions of the French Academy of Science, made 14 recommendations for the future of the launcher.

Among them are recommendations for better preparation and testing of equipment, for the revision of all flight software and for inclusion of "external participants when reviewing specifications, code and justification documents".

The board concludes by recommending "a more transparent organization of the cooperation among the partners in the programme". Luton predicted that "this will be the hardest recommendation to implement". But he promised to follow all the board's advice.

Roni Amelan 